\title{
Effects of Foliar Nutrition on Onion Seed Storage under Modified Atmosphere Packages
}

\author{
Shehata, S. A. ${ }^{1}$, Hashem, M. Y. ${ }^{2}$, Mahmoud, G. I. ${ }^{3}$, Abd El-Gawad, K. F. ${ }^{1}$, El-Ramady, H. R.*4,5 \\ Alshaal, T. A. ${ }^{4,5}$, Domokos-Szabolcsy, É. ${ }^{5}$, Elhawat, N. ${ }^{5,6}$, Prokisch, J. ${ }^{7}$ and Fári, M. ${ }^{5}$ \\ (1) Vegetable Crops Dept., Faculty of Agriculture, Cairo University, Egypt \\ (2) Economic Entomology Dept., Faculty Agriculture, Cairo University, Egypt \\ (3) Biochemistry Dept., Faculty of Agriculture, Cairo University, Egypt \\ (4) Soil and Water Sciences Dept., Fac. of Agriculture, Kafrelsheikh Uni., Kafr El-Sheikh, Egypt \\ (5) Plant Biotechnology Dept., Debrecen Uni., Böszörményi Ú. 138, 4032 Debrecen, Hungary \\ (6) Biological and Environmental Sci. Dept., Faculty of Home Economics, Al-Azhar University, Egypt \\ (7) Bio- and Environmental Enegetics Inst., Debrecen Uni., Böszörményi Ú. 138, 4032 Debrecen, Hungary
}

*Corresponding author: El-Ramady, H. (ramady2000@gmail.com)

\begin{abstract}
Summary: Modified atmosphere packaging (MAP) and controlled atmosphere storage techniques to reduce the oxygen around the food are largely used for the preservation of fresh produce. There have been great technological advances in this area of preservation, particularly as it refers to improving the quality and shelf-stability of highly perishable food products, such as produce. Two successive winter seasons of 2008/2009 and 2009/2010 were conducted under sandy soil conditions to study the effect of spraying with 12 commercial compounds on onion seeds storage under modified atmosphere packages. Germination percent of seeds decreased in $5^{\circ} \mathrm{C}$ than storage in room temperature. Germination percent of seeds was gradually decreased with increasing the storage period. Packaging treatments had a significant effect on germination percent of seeds. All the packaging treatments had the higher germination percent than the paper package (control). The highest germination percent after 12 months of storage was recorded for the treatment with non perforated polypropylene in room temperature and polyethylene and non perforated polypropylene in $5^{\circ} \mathrm{C}$. Catalase activity decreased with the prolongation of storage period. The non perforated polypropylene package had the highest catalase activity. The treatment with non perforated polypropylene had the highest catalase activity after 12 months of storage in both room and $5^{\circ} \mathrm{C}$ temperatures. Peroxidase activity of seeds was gradually decreased with increasing the storage period. The highest peroxidase activity after 12 months of storage was recorded in non perforated polypropylene in both storage temperatures.
\end{abstract}

Keywords: Onion; pre-harvest; post-harvest, foliar application, seeds production, modified atmosphere packages

\section{Introduction}

Fruits and vegetables constitute a vital part of the human diet, with their per capita consumption rate steadily increasing in recent years. Traditionally, fruits and vegetables have been regarded as microbiologically safer than other unprocessed foods, such as meat, milk, eggs, poultry and seafood. Modified atmosphere packaging (MAP) and controlled atmosphere (CA) storage techniques to reduce the oxygen around the food are largely used for the preservation of fresh produce (Kurubar, 2007). The pre- and post-harvest application of chemicals is known to influence the quality and shelf-life of fruits during storage. A brief review of work carried out on the influence of pre- and post-harvest application of calcium compounds on fruits during storage is furnished here. Physiological loss in weight of fruit is mainly due to evaporation, respiration and degradation process occurring during post-harvest handling of fruits. Moisture content of the most of fruits is high and weight loss during transport and storage is an economic factor to be considered especially when sold by weight in market (Kurubar, 2007).

Onion (Allium cepa L.) is one of the oldest bulb crops, known to mankind and consumed worldwide. It is one of the most important commercial vegetable crops grown in Egypt and believed to be originated in Central Asia. It is valued for its distinct pungent flavor and is an essential ingredient for the cuisine of many regions. Onion is the queen of the kitchen (Selvaraj, 1976). Onion is a species of the alliaceae family it is of great economic importance in Egypt. It is the most important cash crop after rice in Egypt. Egypt is considered the $4^{\text {th }}$ producer of dry onion in the world, where it produce about 2,208,080 ton, average yield per hectare is $358833 \mathrm{~kg} \mathrm{ha}^{-1}$ and the total harvested area from dry onion 61535 ha in 2010 (FAO, 2012). The seed production 
programs depend upon quality of seeds, agronomic practices and plant protection measures taken to produce the healthy and vigorous crop. Among the agronomic practices nutrient management through organic sources is considered as an important factor for production. The problem of high cost of chemical fertilizers fully meet out nutrient requirement of crop by single source therefore integrated nutrients management such as organic matters like farmyard manure, vermicompost, poultry manure and biofertilizers use has become necessary (Bendegumbal, 2007).

Therefore, the aim of this study was to investigate the effect of foliar application with 12 commercial compounds as pre-harvest treatments on storage temperature and modified atmosphere packages on onion seed longevity as post-harvest.

\section{Materials and Methods}

\section{Experimental design}

Two grams of seeds were ground in a mortar and homogenized in $20 \mathrm{ml}$ of $0.1 \mathrm{M}$ phosphate puffer $(\mathrm{pH} 7.8)$ containing $0.4 \mathrm{~g}$ polyvinyl pyrrolidone, $2 \mathrm{mM}$ dithiotheitol and $0.1 \mathrm{mM}$ EDTA followed by centrifuging at $16,000 \times \mathrm{g}$ for $15 \mathrm{~min}$ at $4^{\circ} \mathrm{C}$ (Rao et al. 2006). Catalase (CAT), and peroxidase (POD) activity and malondialdehyde (MDA) content were determined according to Chance and Maehly (1955), Amako et al. (1994) and Health and Parker (1968), respectively. For more details about the enzyme activities, it could be seen Shehata et al. (2013).

\section{Storage of onion seed under modified atmosphere packaging (MAP)}

This study was conducted to know more information on the storage life of onion seed beyond 12 months and their behavior after this period in relation to possible release for sowing and sale. This part of the investigation aimed to study the effect of different four modified atmosphere packages (paper bags, polyethylene bags, perforated polypropylene bags and non perforated polypropylene bags) and two storage temperatures (5 C and room temperature) on seed germination, moisture content and change in antioxidant enzymes activity of onion seeds during storage period. Number of treatments was 96 (4 packages $\times 2$ storage temperatures $\times 4$ replicates $\times$ 3 storage periods). Seeds for this investigation were produced at the Agricultural Experiment Station of the Faculty of Agriculture, Cairo University, Waddy Elnatron farm, Egypt, using standard commercial practices without any additional treatments. Thirty two replicates were prepared for each type of MAP and control treatments. Each experimental unit consisted of $75 \mathrm{~g}$ of seeds, and all packages were stored at $5 \mathrm{C}$ and room temperature for 12 months. The following parameters were measured after harvest and every 4 months: seed water content, seed germination, chemical analysis and biochemical assessment (CAT, and POD and MDA content).
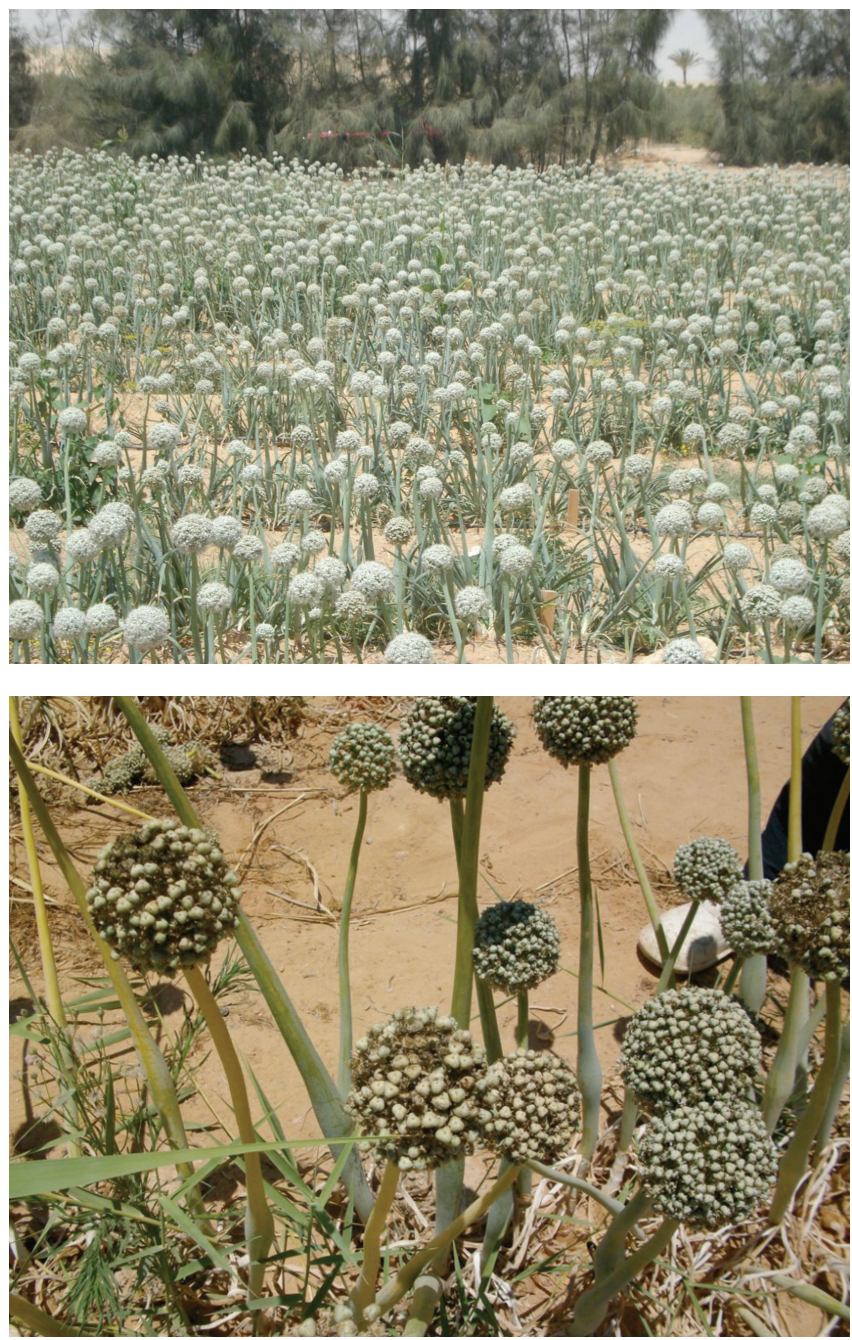

Fig. 1: Waddy Elnatron farm, Agricultural Experimental Station of the Faculty of Agriculture, Cairo University, where onion seed production under reclaimed sandy soil and high temperature. After 4 months, vegetative growth measured such as flower stalks length, inflorescence diameter and number of seeds stalk/plant (photo by K. Abd El-Gawad)

\section{Statistical analysis}

Data were organized in a completely randomized block design (CRBD). Analyses of variance (ANOVA) were obtained using M. State statistical software. The new LSD method (Waller and Duncan, 1969) was used for testing the significance of means in all experiments conducted.

\section{Results}

\section{Storage of onion seed under modified atmosphere packaging}

Seeds of this investigation were produced at the Agricultural Experiment Station of the Faculty of Agriculture, Cairo University, Waddy Elnatron farm, Egypt using standard commercial practices without any additional treatments to study the effect of different modified 
Table 1: Effect of storage temperature, storage period and packaging material on germination ( $\%)$, water content (\%), $\mathrm{O}_{2}$ and $\mathrm{CO}_{2}$ percentages of onion seeds

\begin{tabular}{|c|c|c|c|c|}
\hline Treatments & $\begin{array}{c}\text { Germination } \\
(\%) \\
\end{array}$ & Water content (\%) & Oxygen (\%) & Carbon dioxide $(\%)$ \\
\hline \multicolumn{5}{|l|}{ Storage temperature } \\
\hline $\begin{array}{l}\text { Room temperature } \\
\text { Cold temperature }\left(5^{\circ} \mathrm{C}\right)\end{array}$ & $\begin{array}{l}81.81 \mathrm{a} \\
79.50 \mathrm{a} \\
\end{array}$ & $\begin{array}{l}4.39 \mathrm{~b} \\
4.86 \mathrm{a} \\
\end{array}$ & $\begin{array}{r}19.06 \mathrm{a} \\
19.05 \mathrm{a} \\
\end{array}$ & $\begin{array}{l}0.66 \mathrm{a} \\
0.65 \mathrm{a} \\
\end{array}$ \\
\hline \multicolumn{5}{|l|}{ Storage period (month) } \\
\hline $\begin{array}{c}4 \\
8 \\
12 \\
\end{array}$ & $\begin{array}{l}88.34 \mathrm{a} \\
79.41 \mathrm{~b} \\
74.22 \mathrm{c}\end{array}$ & $\begin{array}{c}4.52 \mathrm{~b} \\
4.76 \mathrm{a} \\
4.59 \mathrm{a}-\mathrm{b}\end{array}$ & $\begin{array}{l}19.7 \mathrm{a} \\
19.2 \mathrm{~b} \\
18.1 \mathrm{c} \\
\end{array}$ & $\begin{array}{l}0.307 \mathrm{c} \\
0.629 \mathrm{~b} \\
1.054 \mathrm{a}\end{array}$ \\
\hline \multicolumn{5}{|l|}{ Packaging treatments } \\
\hline $\begin{array}{l}\text { Paper } \\
\text { Polyethylene } \\
\text { Perforated polypropylene } \\
\text { Non-perforated polypropylene }\end{array}$ & $\begin{array}{l}77.63 \mathrm{~b} \\
82.21 \mathrm{a} \\
81.38 \mathrm{a} \\
81.42 \mathrm{a}\end{array}$ & $\begin{array}{l}4.81 \mathrm{a} \\
4.48 \mathrm{~b} \\
4.79 \mathrm{a} \\
4.41 \mathrm{c}\end{array}$ & $\begin{array}{l}20.9 \mathrm{a} \\
18.5 \mathrm{~b} \\
18.5 \mathrm{~b} \\
18.2 \mathrm{c}\end{array}$ & $\begin{array}{l}0.030 \mathrm{c} \\
0.825 \mathrm{~b} \\
0.812 \mathrm{~b} \\
0.987 \mathrm{a}\end{array}$ \\
\hline
\end{tabular}

atmosphere packages (MAP) and two storage temperatures on seeds storage quality. Onion seeds were stored in different package materials (paper, polyethylene, perforated and non perforated polypropylene) to study the effect of different modified atmosphere packages at two storage temperatures (room temperature and $5^{\circ} \mathrm{C}$ ) on seeds germination, moisture content and change in antioxidant enzymes activities of onion seeds during the storage period.

\section{Germination percent}

\section{Effect of storage temperature on germination percent}

Most packs for MAP products are made from one or more of four polymers: polyvinylchloride (PVC), polyethylene terephthalate (PET), polyethylene (PE) and polypropylene (PP) depending on the features desired for the intended use (Das, 2004).

It appears from data in Table $\mathbf{1 A}$ that germination percent of seeds decreased in cold temperature $\left(5^{\circ} \mathrm{C}\right)$ than storage in room temperature. These results disagree with those obtained by Lazarenko and Bezrukov (2008) as they found that higher seed viability was observed after cold temperature storage compared with storage at room temperature. These results may be due to the increase of water content in the seeds which stored at $5^{\circ} \mathrm{C}$ than at room temperature. These results also are agreed with those of Muhammad and Anjum (2002). They reported that water content of the atmosphere is the most critical factor influence the longevity of onion seeds in the storage and a rise in air moisture being more damaging than raising temperature. Similar results were also obtained by Bass (1981) who reported that the water content is the most important factor involved in the deterioration of seeds.

\section{Effect of storage period on germination percent}

Concerning the effect of storage period on germination percent, data in Table 1A shows that germination percent of seed was gradually decreased with increasing the storage period. These results are in agreement with those obtained by Muhammad and Anjum (2002), Sharma et al. (2004) and Gaviola et al. (2006) as they found that the percentage of germination decreased as storage period increased. They also added that days to $50 \%$ of final germination increased with increasing storage period.

\section{Effect of packaging treatments on germination percent}

Polyethylene is one of the most important packaging materials of the present time. It is a hydrocarbon polymer with the nominal formula $-\left(\mathrm{CH}_{2}-\mathrm{CH}_{2}\right)$ n-. The simplest of all monomers as far as chemical structure concerned is ethylene. Commercial polyethylenes are produced with a variable amount of branching within this nominally linear polymer (Das, 2004).

Packaging treatment had a significant effect on germination percent of seeds. All the packaging treatments had the higher germination percent than the paper package. These results may be due to that packages had lower water content than the paper bag and that these packages had the lowest oxygen and the highest carbon dioxide percentages (Table 1A). These results are in agreement with those obtained by Caneppele et al. (1995) and Stanwood and Sowa (1995).

\section{Water content}

The majority of seeds come into equilibrium between their internal water content and the relative humidity of the atmosphere in which they are stored, and as a general rule within the usual limits of moisture for storage, the life of the seed is halved for each $1 \%$ increase in water content of the seeds. In another studies, Stumpf et al. (1997) found that seeds stored with low water content in hermitic containers may maintain viability for three years. Yanping et al. (2000) reported that several indices of seed vigour, including dehydrogenase activity, germination energy, vigour index and emergence percent of the seeds 
declined as seed water content increased. When the seeds were stored at room temperature or $6^{\circ} \mathrm{C}$ for two years, the indices were significantly influenced by the seed water content. The increase of seed water content resulted in the significant decrease of the indices, some of which were reduced to zero. Onion seeds have a short life and can not store for more than 4 months when the water content is higher than 10\% (Rocha, 1959). Thus, the seed require reduction of the water content to less than $7.5 \%$ in order to minimize the deterioration process. In open environmental conditions, onion seed equilibrate their water content at $60 \%$ R. H. to more than $7.5 \%$. Thus, in order to keep the water content low, it is necessary to store them in hermetic moisture containers (Deluche and Baskin, 1973).

\section{Effect of storage temperature on water content}

It appears from data in Table $\mathbf{1}$ that the water content of seeds increased in $5^{\circ} \mathrm{C}$ than storage in room temperature (4.86 and 4.39, respectively). These results are in agreement with those obtained by Stanwood and Sowa (1995) and Yanping et al. (1999).

\section{Effect of storage period on water content}

Table 1 show that water content of seeds was gradually increased with increasing the storage period and reached its maximum peak after 8 months of storage and then decline after 12 months of storage (4.52, 4.76 and 4.59 , respectively) but the decline was insignificant. These results are in agreement with those obtained by Kavak and Eser (2009) who found that the water content of onion seed had raised from $9 \%$ to $13 \%$ during storage.

\section{Effect of packaging treatment on water content}

Packaging treatment had a significant effect on water content of seeds. The lowest values of water content were observed in non perforated polypropylene and polyethylene (4.41 and $4.48 \%$, respectively, Table 1). This reduction of water content was due to that the non perforated polypropylene and Polyethylene film packaging which did not allow moisture to transpire from the atmosphere to the seeds. These results are in agreement with those of Shelar $\boldsymbol{e t}$ al (1992) as they reported that the difference in performance of onion germination and seedling which stored in impermeable packaging was due to changes in seed water content and to the degree of hygroscopic equilibrium between seeds and their surroundings.

\section{Oxygen percentage}

It appears from data in Table $\mathbf{1}$ that there was non significant difference between storage temperatures on oxygen percentage inside all tested packages. Concerning the effect of storage period on oxygen percentage, data in Table 1 shows that oxygen percent inside the package of seeds was gradually decreased with increasing the storage period. The reduction in oxygen during storage could be due to respiration process of onion seeds. The treatment of non perforated polypropylene had the lowest oxygen percentage compared to all other tested treatments followed by the treatment of perforated polypropylene and polyethylene packages, meanwhile, the paper bag showed the highest oxygen percentage.

The results illustrated in Table 2 show that percent of oxygen at both storage temperatures decreased as storage period increased. The lowest oxygen percentage was recorded after 12 months of storage at both storage temperatures (18.19 for room and $5{ }^{\circ} \mathrm{C}$ temperature). The treatment of non perforated polypropylene had the lowest oxygen percentage at both storage temperatures compared with all other tested treatments (18.2\%, Table $\mathbf{1})$.

\section{Carbon dioxide percentage}

It appears from data in Table $\mathbf{1}$ that there was non significant difference between storage temperatures on carbon dioxide (\%) inside the package of seeds. Concerning the effect of storage period on carbon dioxide percentage, carbon dioxide percentage inside the package of seeds was gradually increased with the prolongation of storage period. Packaging treatments had a significant effect on carbon dioxide percentage (Table 1). The treatment of non perforated polypropylene packaging had the highest carbon dioxide percent compared with all other treatments followed by perforated polypropylene and polyethylene $(0.987,0.825$ and 0.812 , respectively). The results illustrated in Table 2 show that the percent of carbon dioxide at both storage temperatures increased as storage period increased. The highest percentage of carbon dioxide was recorded after 12 months of storage at both storage temperatures (1.07 and $1.03 \%$ for room and $5{ }^{\circ} \mathrm{C}$ temperature, respectively).

\section{Effects on biochemical assessments}

\section{Catalase activity}

\section{Effect of storage temperature on catalase activity}

The results illustrated in Table 2 show that storage temperature had insignificant effect on catalase activity, but there was a slight increase in catalase activity at room temperature than at $5^{\circ} \mathrm{C}$. These results disagree with those of Demirkaya et al. (2010). They found a significant effect of storage temperature on antioxidant activity and they reported that as storage temperature increased the catalase activity decreased. 
Table 2: Effect of storage temperature, storage period and packaging material on catalase and peroxidase activities and malondialdehyde

\begin{tabular}{|c|c|c|c|}
\hline Treatments & $\begin{array}{c}\text { Catalase activity } \\
\left(\mu \mathrm{mol} \mathrm{H}_{2} \mathrm{O}_{2} \text { consumed } / \mathrm{mg} \text { protein }\right. \\
/ \mathrm{min})\end{array}$ & $\begin{array}{l}\text { Peroxidase activity } \\
\quad \text { (enzyme unit) }\end{array}$ & $\begin{array}{c}\text { Malondialdehyde } \\
\text { content }\left(\mathrm{mmol} \mathrm{g}^{-1} \mathbf{f w}\right)\end{array}$ \\
\hline \multicolumn{4}{|l|}{ Storage temperature } \\
\hline $\begin{array}{l}\text { Room temperature } \\
\text { Cold temperature }\left(5^{\circ} \mathrm{C}\right)\end{array}$ & $\begin{array}{l}15.59 \mathrm{a} \\
14.09 \mathrm{a}\end{array}$ & $\begin{array}{r}10.56 \mathrm{a} \\
9.83 \mathrm{a} \\
\end{array}$ & $\begin{array}{l}17.30 \mathrm{~b} \\
18.42 \mathrm{a}\end{array}$ \\
\hline \multicolumn{4}{|l|}{ Storage period (month) } \\
\hline $\begin{array}{c}0 \\
6 \\
12 \\
\end{array}$ & $\begin{array}{l}20.37 \mathrm{a} \\
12.79 \mathrm{~b} \\
11.36 \mathrm{~b} \\
\end{array}$ & $\begin{array}{r}14.05 \mathrm{a} \\
8.88 \mathrm{~b} \\
7.65 \mathrm{~b} \\
\end{array}$ & $\begin{array}{l}13.80 \mathrm{c} \\
18.48 \mathrm{~b} \\
21.30 \mathrm{a} \\
\end{array}$ \\
\hline \multicolumn{4}{|l|}{ Packaging treatments } \\
\hline $\begin{array}{l}\text { Paper } \\
\text { Polyethylene } \\
\text { Perforated polypropylene } \\
\text { Non-perforated polypropylene }\end{array}$ & $\begin{array}{c}14.14 \mathrm{~b} \\
14.34 \mathrm{ab} \\
15.01 \mathrm{ab} \\
15.89 \mathrm{a}\end{array}$ & $\begin{array}{r}9.61 \mathrm{a} \\
10.32 \mathrm{a} \\
10.58 \mathrm{a} \\
10.28 \mathrm{a}\end{array}$ & $\begin{array}{l}19.19 \mathrm{a} \\
17.23 \mathrm{c} \\
17.99 \mathrm{~b} \\
17.02 \mathrm{c}\end{array}$ \\
\hline
\end{tabular}

\section{Effect of storage period on catalase activity}

Concerning the effect of storage period on catalase activity, data in Table 2 show that the catalase activity decreased with the prolongation of storage period (20.37, 12.79 and $11.36 \mu$ mol $\mathrm{H}_{2} \mathrm{O}_{2}$ consumed $\mathrm{mg}^{-1}$ protein min ${ }^{1}$ for 0,6 and 12 month, respectively). These results are in agreement with those obtained by Xin and Wang (2006) and Demirkaya et al. (2010).

\section{Effect of packaging treatment on catalase activity}

These results indicated that the packaging had a significant effect on catalase activity. The non perforated polypropylene had the highest catalase activity followed by perforated polypropylene and polyethylene $(15.89,15.01$ and $14.34 \mu \mathrm{mol}$ $\mathrm{H}_{2} \mathrm{O}_{2}$ consumed $\mathrm{mg}^{-1}$ protein $\mathrm{min}^{-1}$, respectively; Table 2 ). These results may be due to that this package had the lowest water content and oxygen percentage and the highest carbon dioxide percent (Table 1). These results are in agreement with Ilbi and Eser (2006) and Xin and Wang (2006).

\section{Peroxidase activity}

\section{Effect of storage temperature on peroxidase activity}

The results illustrated in Table 2 show that the storage temperature had insignificant effect on peroxidase activity. These results disagree with those of Yanping $\boldsymbol{e t}$ al. (2000) and Demirkaya $\boldsymbol{e t}$ al. (2010). They found that as storage temperature increased the peroxidase activity decreased (10.56 and 9.83 enzyme unit for room and $5{ }^{\circ} \mathrm{C}$ temperature, respectively).

\section{Effect of storage period on peroxidase activity}

Concerning the effect of storage period on peroxidase activity, data in Table 1 show that peroxidase activity of seeds was gradually decreased with increasing the storage period $(14.05,8.88$, and 7.65 for 0,6 and 12 month, respectively). These results are in agreement with those obtained by Xin and Wang (2006) and Demirkaya et al. (2010).

\section{Effect of packaging treatment on peroxidase activity}

These results indicated that the packaging treatment had insignificant effect on peroxidase activity (Table 2). These results are disagreeing with those obtained by Ilbi and Eser (2006). They found a significant effect of modified atmosphere package on peroxidase activity. The perforated polypropylene had highest peroxidase activity followed by polyethylene and non perforated polypropylene (10.58, 10.32 and 10.28 enzyme unit, respectively; Table 2 )

\section{Malondialdehyde content}

\section{Effect of storage temperature on malondialdehyde content}

Results illustrated in Table $\mathbf{2}$ show that storage temperature had a significant effect on malondialdehyde content. Room temperature had the lower malondialdehyde content than $5^{\circ} \mathrm{C}$. These results disagree with those of Yanping et al. (2000) and Demirkaya et al. (2010). They found that as storage temperature increased the malondialdehyde content increased. These results may be due to increasing the water content in the seed stored at cold temperature than at room temperature.

\section{Effect of storage period on malondialdehyde content}

With respect to the effect of storage period on malondialdehyde content, data in Table 2 show that malondialdehyde content increased as storage period increased (from 13.8, 18.48 and $21.3 \mathrm{mmol} \mathrm{g}^{-1} \mathrm{fw}$ for 0,6 and 12 month, respectively). These results agree with those of Xin and Wang (2006) and Demirkaya et al. (2010). 
Table 3: Effect of the interaction between storage temperature and storage period on germination (\%) water content (\%), oxygen and carbon dioxide percentages, catalase and peroxidase activities malondialdehyde content of onion seeds

\begin{tabular}{|c|c|c|c|c|c|c|}
\hline \multirow[t]{2}{*}{ Storage temperature } & \multicolumn{6}{|c|}{ Storage period (month) } \\
\hline & 4 & 8 & 12 & 4 & 8 & 12 \\
\hline & \multicolumn{3}{|c|}{ Germination (\%) } & \multicolumn{3}{|c|}{ Water content $(\%)$} \\
\hline Room temperature & $90.38 \mathrm{a}$ & $80.13 \mathrm{c}$ & $74.94 \mathrm{~d}$ & $4.46 \mathrm{~d}$ & $4.71 \mathrm{~b}$ & $4.00 \mathrm{e}$ \\
\hline \multirow[t]{2}{*}{ Cold temperature $\left(5^{\circ} \mathrm{C}\right)$} & $86.31 \mathrm{~b}$ & $78.69 \mathrm{c}$ & $73.50 \mathrm{~d}$ & $4.59 \mathrm{c}$ & $4.81 \mathrm{~b}$ & $5.18 \mathrm{a}$ \\
\hline & \multicolumn{3}{|c|}{ Oxygen $(\%)$} & \multicolumn{3}{|c|}{ Carbon dioxide (\%) } \\
\hline Room temperature & $19.6 \mathrm{a}$ & $19.3 \mathrm{~b}$ & $18.19 \mathrm{~d}$ & $0.30 \mathrm{~d}$ & $0.62 \mathrm{c}$ & $1.07 \mathrm{a}$ \\
\hline \multirow[t]{2}{*}{ Cold temperature $\left(5^{\circ} \mathrm{C}\right)$} & $19.7 \mathrm{a}$ & $19.2 \mathrm{c}$ & $18.19 \mathrm{~d}$ & $0.30 \mathrm{~d}$ & $0.63 \mathrm{c}$ & $1.03 \mathrm{~b}$ \\
\hline & \multicolumn{3}{|c|}{ Catalase activity } & \multicolumn{3}{|c|}{ Peroxidase activity } \\
\hline Room temperature & $20.37 \mathrm{a}$ & $13.98 \mathrm{~b}$ & $12.42 \mathrm{bc}$ & $14.05 \mathrm{a}$ & $9.55 \mathrm{~b}$ & $8.05 \mathrm{~b}-\mathrm{c}$ \\
\hline \multirow[t]{2}{*}{ Cold temperature $\left(5^{\circ} \mathrm{C}\right)$} & $20.37 \mathrm{a}$ & $11.61 \mathrm{bc}$ & $10.29 \mathrm{c}$ & $14.05 \mathrm{a}$ & $8.21 \mathrm{~b}-\mathrm{c}$ & $7.24 \mathrm{c}$ \\
\hline & \multicolumn{6}{|c|}{ Malondialdehyde content $\left(\mathrm{mmol} \mathrm{g}^{-1} \mathbf{f w}\right)$} \\
\hline Room temperature & $13.80 \mathrm{e}$ & $17.51 \mathrm{~d}$ & $20.59 \mathrm{~b}$ & & & \\
\hline Cold temperature $\left(5^{\circ} \mathrm{C}\right)$ & $13.80 \mathrm{e}$ & $19.45 \mathrm{c}$ & $22.01 \mathrm{a}$ & & & \\
\hline
\end{tabular}

\section{Effect of packaging treatment on malondialdehyde content}

These results indicated that the packaging treatment had a significant effect on malondialdehyde content. The lowest malondialdehyde content (17.02 mmol g-1 fw) was found in non perforated polypropylene and polyethylene packages (17.23 mmol g-1 fw) (Table 2).

\section{Discussion}

The onion is preferred mainly because of its green leaves, immature and mature bulbs are either eaten raw or cooked as a vegetable. Mild flavored or colorful bulbs are often chosen for salads. The bulbs are used in soups, sauces, condiments, spice, in medicine, seasoning of many foods and for the preparation of value added edible products like powder, flakes and salts. Onion has many uses as folk medicine and recent reports suggests that onion plays an important role in preventing heart diseases and other ailments (Kukanoor, 2005). Quality optimization and loss reduction in the postharvest chain of fresh fruits and vegetables are the main objectives of postharvest technology. Temperature control and modification of atmosphere are two important factors in prolonging shelf life. Modified atmosphere packaging (MAP) of fresh produce relies on modification of the atmosphere inside the package, achieved by the natural interplay between two processes, the respiration of the product and the transfer of gases through the packaging, that leads to an atmosphere richer in $\mathrm{CO}_{2}$ and poorer in $\mathrm{O}_{2}$. This atmosphere can potentially reduce respiration rate, ethylene sensitivity and production, decay and physiological changes, namely, oxidation (Gorris and Tauscher, 1999).

MAP was first recorded in 1927 as an extension of shelf life of apples by storing them in atmospheres with reduced $\mathrm{O}_{2}$ and increased $\mathrm{CO}_{2}$ concentrations. In the 1930s, it was used as modified atmosphere storage to transport fruits in the holds of ships and increasing the carbon dioxide concentration surrounding beef carcasses transported long distances was shown to increase shelf life by up to $100 \%$. However, the technique was not introduced commercially for retail packs until the early 1970s in Europe (Das, 2004). MA packages should be carefully designed, as a system incorrectly designed may be ineffective or even shorten the shelf life of the product. The design should take into consideration not only steady-state conditions, but also the dynamic process, because if the product is exposed for a long time to unsuitable gas composition before reaching the adequate atmosphere, the package may have no benefit. The design of an MA package depends on a number of variables: the characteristics of the product, its mass, the recommend atmosphere composition, the permeability of the packaging materials to gases and its dependence on temperature and the respiration rate of the product as affected by different gas composition and temperature. Thus, respiration rate modeling is central to the design of MAP for fresh fruits and vegetables (Fonseca et al. 2002).

An important goal in some modified atmosphere packaging systems is to generate an atmosphere sufficiently low in $\mathrm{O}_{2}$ to influence the metabolism (e.g., softening, chlorophyll degradation, tissue browning, senescence) of the product being packaged such that storability and/or shelf life is extended. For some products, modifying both $\mathrm{O}_{2}$ and $\mathrm{CO}_{2}$ may be desirable and indeed, when the $\mathrm{O}_{2}$ partial pressure in packages is altered, so too must be that of $\mathrm{CO}_{2}$ by virtue of the system (Beaudry, 2000). Modified atmospheres can be created either passively by the commodity or intentionally through active packaging. Modified atmospheres can passively evolve within a hermetically sealed package as a consequence of a commodity's respiration, i.e. $\mathrm{O}_{2}$ consumption and $\mathrm{CO}_{2}$ evolution. The rate of change of the composition of the modified atmosphere will depend largely on the packaged product and the permeability of the packaging material (Das, 2004).

As mentioned before, packaging treatment had a significant effect on germination (\%) of seeds and all the 
packaging treatments had the higher germination (\%) than the paper package. These results may be due to that packages had lower water content than the paper bag and that these packages had the lowest oxygen and the highest carbon dioxide percentages (Table 1A). These results are in agreement with those obtained by Caneppele et al. (1995) and Stanwood and Sowa (1995). Similar results were obtained by Promila et al. (1999) as they found that seed with higher moisture content between $7.0 \%-10.9 \%$ and stored in cloth bags showed more abnormal cells for a given decrease in germination ability upon storage than seeds with reduced water and stored in polythene bags or paper lined aluminium bags. They also reported that the difference was due to changes in seeds water content in impermeable packages and to the degree of hygroscopic equilibrium between seeds and their surrounding. The results had the same trend with Karim et al. (2006) and Rao et al. (2006). In general, the perforated polypropylene or non perforated polypropylene were the most suitable for modified atmospheric packages after foliar nutrition of onion seeds under sandy soil and saline irrigation water in Egypt, whereas they had the highest germination percent and enzyme activity and the lowest moisture and malondialdehyde content during all storage periods.

\section{Conclusion}

Modified atmosphere packaging (MAP) was first recorded in 1927 as an extension of shelf life of apples by storing them in atmospheres with reduced $\mathrm{O}_{2}$ and increased $\mathrm{CO}_{2}$ concentrations. In the $1930 \mathrm{~s}$, it was used as modified atmosphere storage to transport fruits in the holds of ships and increasing the $\mathrm{CO}_{2}$ concentration surrounding beef carcasses transported long distances was shown to increase shelf life by up to $100 \%$. However, the technique was not introduced commercially for retail packs until the early 1970s in Europe. MAP techniques are now used on a wide range of fresh or chilled foods, including raw and cooked meats and poultry, fish, fresh pasta, fruit and vegetables, and more recently, coffee, tea and bakery products.

Onion seeds were stored in different package materials (paper, polyethylene, perforated and non perforated polypropylene) to study the effect of different modified atmosphere packages at two storage temperatures (room temperature and $5^{\circ} \mathrm{C}$ ) on seeds germination, moisture content and change in antioxidant enzymes activities of onion seeds during the storage period. The non perforated polypropylene and polyethylene packages had the highest germination percent and enzyme activity and the lowest moisture and malondialdehyde content during all storage periods.

\section{References}

Amako, A., K. Chen and K. Asada (1994). Separate assays specific for ascorbate peroxidase and guaiacol peroxidase and for the chloroplastic and cytosilic isoenzymes of ascorbate peroxidase in plant. Plant Cell Physiology, 35: 497-504.
Bass, L. N. (1981). Seed viability during long-term storage. Hort. Rev., 2: 117-141.

Beaudry, R. M. (2000). Responses of Horticultural Commodities to Low Oxygen: Limits to the Expanded Use of Modified Atmosphere Packaging. Hort Technology, Vol. July-September 2000 10(3): 491 -500 .

Bendegumbal, C. S. (2007). Studies on effect of organics on seed yield and quality in onion (Allium cepa L.) cv. N-53. M. Sc. Thesis. Department of Seed and Technology, College of Agriculture, University of Agricultural Sciences, Dharwad- 580 005, India.

Caneppele, M. A. B., R. F. d. Silva, E. M. Alvarenga, J. H. Campelo -Junior and A. A. Cardoso (1995). Influence of packaging, environment and storage period on seed quality in onion (Allium cepa L.). Revista Brasileira de Sementes, 17(2): 249-257. Cited from $\mathrm{CAB}$ Abstracts.

Chance, B.; A. C. Maehly (1955). Assay of catalase and peroxidase. Methods in Enzymology, 2: 764-775.

Das, $\boldsymbol{E}$. (2004). Effect of controlled atmosphere storage, modified atmosphere packing and gaseous ozone treatment on the survival characteristics of Salmonella enteritidis at cherry tomatoes. Master of Science in Food Engineering, the Graduate School of Natural and Applied Sciences, Middle East Technical Uni., India.

Deluche, J. C. and C. C. Baskin (1973). Accelerated ageing techniques for predicting the relative storability of seed lots. Seed Sci. Technol., 1: 427-452.

Demirkaya, M., K. J. Dietz, and H. Ö. Sivritepe (2010). Changes in Antioxidant Enzymes during Ageing of Onion Seeds. Not. Bot. Hort. Agrobot. Cluj, Vol. 38 (1): 49-52.

FAO (2012). Major food and agricultural commodities and producers - Fao.org. http://faostat.fao.org/site/567/DesktopDefault. aspx?PageID=567\#ancor Retrieved 2012-07-22.

Fonseca, S. C., F. A. R. Oliveira and J. K. Brecht (2002). Modelling respiration rate of fresh fruits and vegetables for modified atmosphere packages: a review. Journal of Food Engineering, Vol. 52: 99-119.

Gaviola, J., A. Ordovini, R. Lepez and M. A. Makuch (2006). Evolution of onion seed quality stored in non-controlled conditions. Agricultura Tecnica, 66(1): 13-20. Cited from CAB Abstracts.

Gorris, L. and B. Tauscher (1999). Quality and safety aspects of novel minimal processing technology. In: F. A. R. Oliveira, \& J. C. Oliveira (Eds.). Processing of foods: Quality optimization and process assessment (pp. 325-339). Boca Raton, USA: CRC Press.

Health, R. L. and L. Parker (1968). Peroxidation in isolated chloroplasts. 1. Kinetics and stoichiometry of fatty acid peroxidation. Arch. Biochem. Biophys., 125: 189-198.

Ilbi, H. and B. Eser (2006). The potential of vigour tests to identify differences in the extent of ageing in onion seeds. Seed Science and Technology, 34( 3): 713-718.

Karim, M. R., M. A. Rahim, G. A. Fakir and H. R. Anwar (2006). Effect of storage containers, moisture contents and storage conditions on seed health of onion. International Journal of Sustainable Agricultural Technology, 2 (6): 9-13.

Kavak, S. and B. Eser (2009). Influence of polymer coating on water uptake and germination of onion (Allium cepa L. cv. Aki) seeds before and after storage. Scientia Horticulturae, No. 121: 7-11.

Kurubar, A R. (2007). Studies on integrated nutrient and post harvest management of fig (Ficus carica L.). Ph. D. Thesis, Department 
of Horticulture, College of Agriculture, University of Agricultural Sciences, Dharwad- 580 005, India.

Kurubar, L. (2005). Post-harvest studies in onion Cv. N- 53. Ph. D. Thesis, Department of Horticulture, College of Agriculture, University of Agricultural Sciences, Dharwad- 580 005, India.

Lazarenko, L. M. and V. F. Bezrukov (2008). Dynamics of chromosomal instability in welsh onion (Allium fistulosum L.): influence of seed storage temperature. Cytology and Genetics, 42 (5): 335-341.

Muhammad, A. and M. A. Anjum (2002). Effect of relative humidity and ageing on the quality of onion seed. International Journal of Agriculture and Biology, 4(2): 291-296.

Promila, K., S. Kumar, T. M. Vargheese, M. K. Banerjee and C. Ram (1999). Mitotic index and chromosomal aberrations during first mitosis in relation to germinability of stored onion seeds. Vegetable Science, 26(1): 50-54. cited from CAB Abstracts.

Rao, R. G. S., P. M. Singh and M. Rai (2006). Storability of onion seeds and effects of packaging and storage conditions on viability and vigour. Scientia Horticulturae, No. 110: 1-6.

Rocha, F. F. (1959). Interaction of moisture content and temperature on onion seed viability. Proceedings of the American Society of Horticultural Science, 73: 385-389.

Selvaraj, S. (1976). Onion: Queen of the kitchen. Kisan World, 3(12): 32-34.

Sharma, M. K., S. Karan and Gill O. P. (2004). Efficacy of dry permeation seed treatment with plant growth regulators in onion
(Allium cepa L.) genotypes. Journal of Eco Physiology, 7(3/4): 101104.

Shehata, S. A., M. Y. Hashem, G. I. Mahmoud, K. F. Abd ElGawad, H. R. El-Ramady, T. A. Alshaal, É. Domokos-Szabolcsy, N. Elhawat, J. Prokisch and M. Fári (2013). Effect of foliar nutrition on postharvest of onion seed under sandy soil and saline irrigation water conditions. International Hungarian Journal for Horticulture (in press).

Shelar, V. R., R. B. Patil and N. D. Gawade (1992). Onion seed viability influenced by different storage containers. Onion Newsletter for the Tropics, (4): 39-42. cited from CAB Abstracts.

Stanwood, P. C. and S. Sowa (1995). Evaluation of onion (Allium сера) seed after 10 years of storage at 5, -18, and -196 degrees C. Crop Science, 35(3): 852-856.

Stumpf, C. L., S. T. Peske and L. Baudet (1997). Storage potential of onion seeds hermetically packaged at low moisture content. Seed Science and Technology, 25 (1): 25-33.

Waller, R. A. and D. B. Duncan (1969). A bays rule for the symmetric multiple comparison problems. Amer. Stat. Assoc. J., 64: 1485-1503.

Xin, L. and Q. Wang (2006). The changes of the seed vigor of welsh onion under ultra-dry storage. China Vegetables. 8, 10-13. Cited from CAB Abstracts.

Yanping, Y., G. Rongqi, S. Qingquan and L. Shengfu (2000). Vigour of welsh onion seeds in relation to storage temperature and seed moisture content. Seed Science and Technology, 28(3): 817-823. 